\title{
23. STRATIGRAPHIC IMPLICATIONS OF EARLY CRETACEOUS SPORES AND POLLEN GRAINS AT HOLES 638B, 638C, AND 641C, LEG 103, OFF THE IBERIAN MARGIN, EASTERN NORTH ATLANTIC1
}

\author{
Josette Taugourdeau-Lantz, Laboratoire de Micropaléontologie, Université Paris VI, France
}

\begin{abstract}
About 80 species of spores and pollen grains were recorded during detailed palynological investigations of selected Lower Cretaceous sections from Holes $638 \mathrm{~B}$ and $638 \mathrm{C}$ and the bottom of Hole $641 \mathrm{C}$. Most of them are long-ranging taxa with worldwide distribution. However, on the Iberian margin and in the southern European basins, Trilobosporites canadensis, Trilobosporites bernissartensis, Parvisaccites amplus, Foveosporites subtriangularis, and Ephedripites multicostatus seem to be index species of the Valanginian to late Aptian interval. Clavatipollenites was not recovered in the Barremian marginal marine sediments.
\end{abstract}

\section{INTRODUCTION}

Site 638 of Ocean Drilling Program (ODP) Leg 103 (Fig. 1) is on a tilted fault block on the outer part of the Galicia margin. Two holes were cored at this site (Holes 638B and 638C) at $42^{\circ} 09.2^{\prime} \mathrm{N}, 12^{\circ} 11.8^{\prime} \mathrm{W}$. The main objective for drilling at Site 638 was to explore the entire pre-rift sequence and lower part of the syn-rift sequence to complement previous drilling results at Site 398 of Deep Sea Drilling Project (DSDP) Leg 47B (Sibuet, Ryan, et al., 1979). Drilling at Site 638 recovered Lower Cretaceous turbidite beds beneath the seismic reflector that had been identified prior to drilling as the top of the pre-rift carbonate platform (see "Site 638" chapter; Shipboard Scientific Party, 1987a). This discovery has important implications for interpretations of seismic profiles of the Iberian margin, and therefore, the correct stratigraphic assignment of fossil material in these turbidites is of consequence. Site 641 , at $42^{\circ} 09.3^{\prime} \mathrm{N}, 12^{\circ} 10.3^{\prime} \mathrm{W}$, is about $1.2 \mathrm{~km}$ from Site 638 (Fig. 1). The drilling objective was to core the syn-rift Cretaceous sequence and the post-rift sequence. Microturbidites and turbidites were found in Hole $641 \mathrm{C}$ from Sample 103-641C-8R-1, $0 \mathrm{~cm}$, to Section 103-641C-16R, CC (see "Site 641" chapter; Shipboard Scientific Party, 1987b). The spores and pollen grains recovered in these Site 638 and 641 sediments were the subject of this study.

\section{Materials and Methods}

Thirty-six samples from Sites 638 and 641 were processed for palynological examination by standard chemical maceration techniques, using a sequence of hydrochloric acid, hydrofluoric acid, and hydrochloric acid again, followed by sieving on $10-\mu$ m nylon mesh. Potassium hydroxide and nitric acid were not used. The slides were mounted in glycerine jelly and are stored in the Laboratoire de Micropaléontologie, Université Paris VI, France.

The section cored at Hole 638B was the most important in terms of the stratigraphic interval recovered and the number of samples available for study. It was therefore studied first to establish the stratigraphic distribution of the spores and pollen grains (Table 1). The assemblages recovered at Hole $638 \mathrm{C}$ (Table 2) were analyzed by comparison with those occurring in Hole 638B.

\footnotetext{
${ }^{1}$ Boillot, G., Winterer, E. L., et al., 1988. Proc. ODP, Sci. Results, 103: College Station, TX (Ocean Drilling Program).
}

The stratigraphic significance of some species identified as index forms is discussed in comparison with their occurrence in the Atlantic at the following DSDP drill sites:

Sites 101, 105, 387, and 391 (Habib, 1977, 1978, 1979)

Sites 367 and 370 on the African margin (Kotova, 1978)

Sites 400 and 402 (Batten, 1979)

Hole 398D (Habib, 1979; Taugourdeau-Lantz et al., 1982)

Age assignments were made by comparison with spore and pollen occurrences in stratotype outcrops (Hughes and Moody-Stuart, 1966; Norris, 1969; de Renéville and Raynaud, 1981; Srivastava, 1984) and in European continental basins (Delcourt and Sprumont, 1955; Döring, 1966; Kemp, 1970; Batten, 1973; Hughes and Croxton, 1973; Dörhöf-

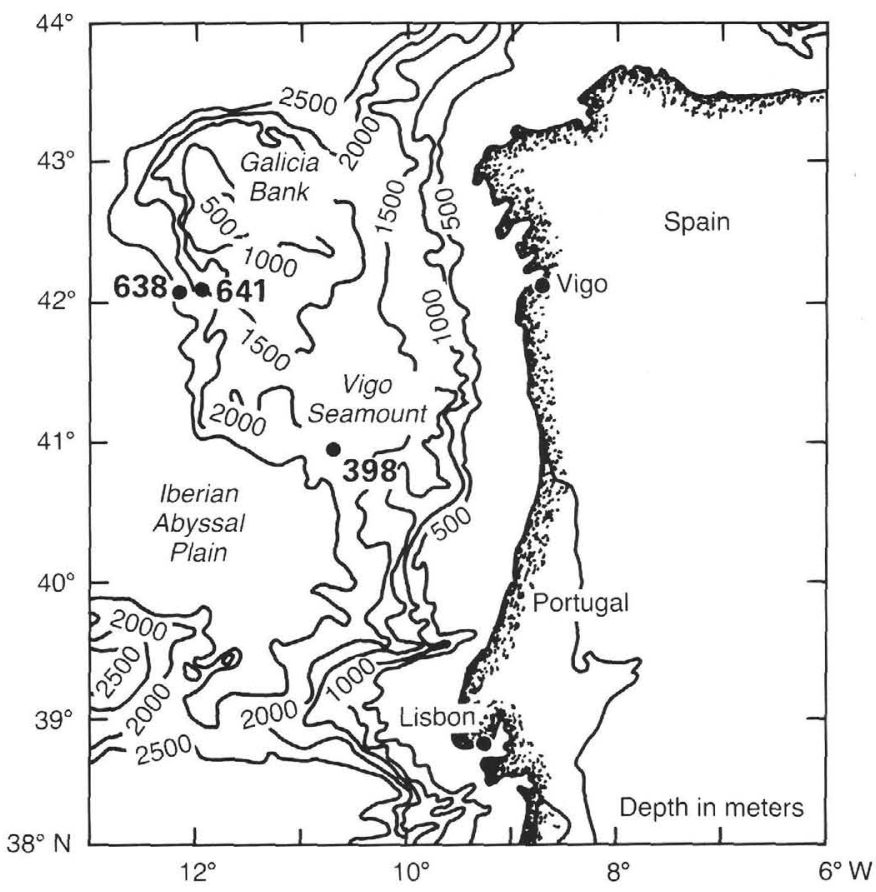

Figure 1. Geographic location of ODP Sites 638 and 641 and DSDP 398 on the Iberian margin. 
Table 1. Stratigraphic distribuiton of spores and pollen grains in Holes 638B and 641C. Star $=$ index species. Species list is given in the Appendix.



fer, 1977; Hughes and McDougall, 1987). Because Iberia and North America were in close proximity during the Early Cretaceous, the spores and pollen grains are also compared with index species in North America (Pocock, 1962; Brenner, 1963; Singh, 1964; Srivastava, 1981).

\section{RESULTS AND DISCUSSION}

The stratigraphic distribution of only five taxa, selected from among the approximately 80 taxa of spores and pollen grains recorded, are discussed in this paper. Most of the spore and pollen species occurring in the Lower Cretaceous section first appeared during the Jurassic and disappeared progressively during the Albian. The distinctive cicatricose morphotype encountered in the Berriasian became an important component in younger strata, but its stratigraphic significance is not known in deep marine sediments.
The genus Trilobosporites is generally abundant in the Berriasian and Valanginian section (Delcourt and Sprumont, 1953; Burger, 1966; Taugourdeau-Lantz and Donze, 1971; Dörhöffer and Norris, 1975; Dörhöffer, 1977, 1979). In the samples studied here, however, only rare specimens were recovered and their size is of the smaller end of the range of the species.

Trilobosporites canadensis occurs at the base of Hole 638B in Sample 103-638B-43R-1, 29 cm. Above, in Sample 103-638B37R-1, $46 \mathrm{~cm}$, Trilobosporites apiverrucatus occurs with Trilobosporites tenuiparietalis. In Hole $638 \mathrm{C}, T$. canadensis also occurs, near the base of the section in Sample 103-638C-10R-2, 87 $\mathrm{cm}$. All three species have their first appearance in the Berriasian, and T. tenuiparietalis is restricted to this age according to Dörhöffer (1979). This spore, however, is rarely recovered. In the Berriasian-Valanginian of the Algarve (southern Portugal), 
Table 1 (continued).

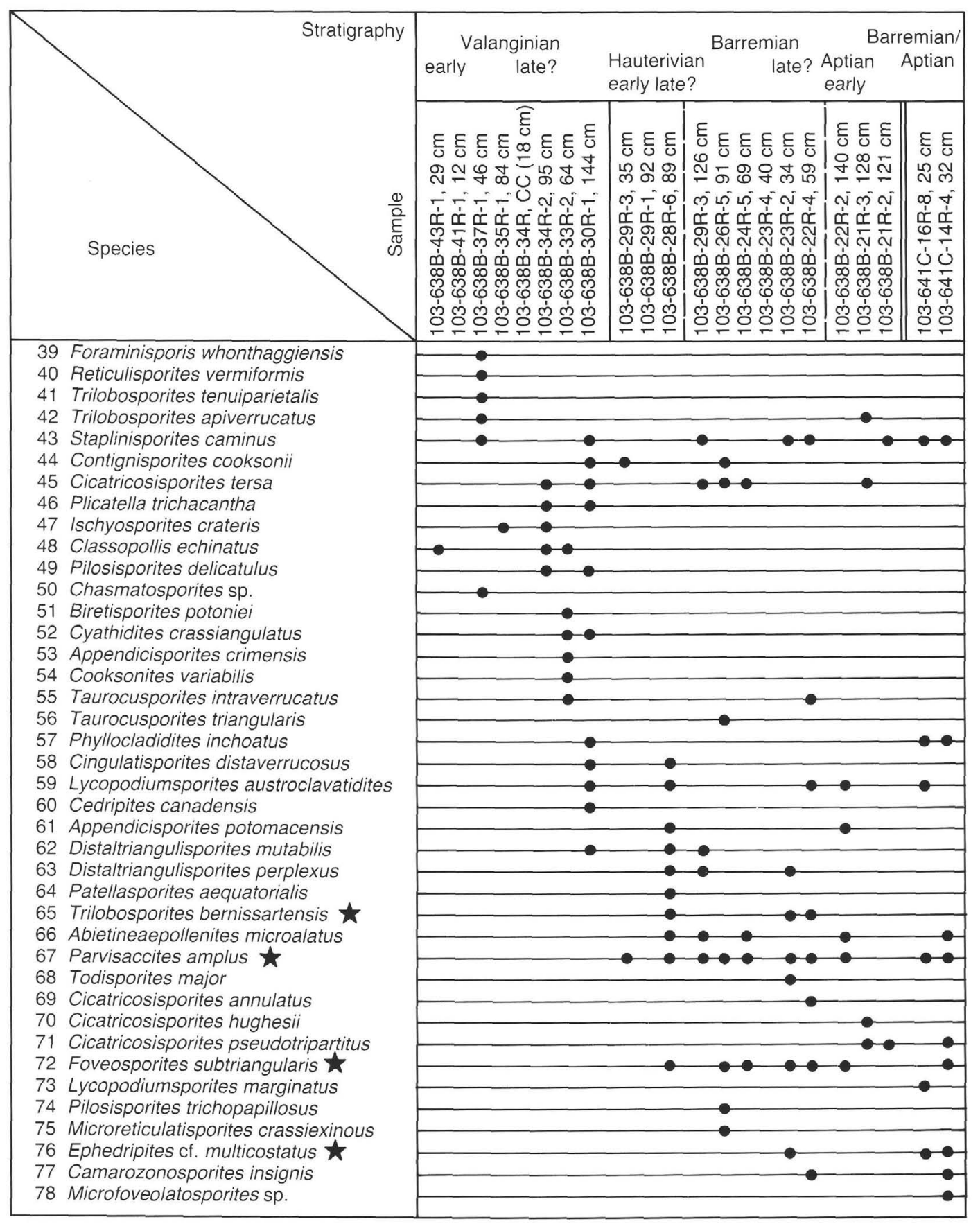

Berthou et al. (1983) recovered numerous examples of Trilobosporites aornatus, T. canadensis, Trilobosporites bernissartensis, and $T$. apiverrucatus. T. aornatus, a spore often present in Berriasian assemblages, was not observed in Hole 638B, which suggests a probable early Valanginian age for the section containing these samples.

In Hole 638B, T. bernissartensis occurs up to Sample 103638B-22R-4, $59 \mathrm{~cm}$. In DSDP Hole 398D, Taugourdeau-Lantz et al. (1982) recovered this species up to Sample 398D-129-7, 34 $\mathrm{cm}$, of late Barremian age (Müller et al., 1983, 1984). Habib (1979, pl. 2, fig. 3) illustrated a spore identified as cf. Trilobosporites. This spore lacks verrucae on the valvae like $T$. bernissartensis and occurs in Hole 398D in Sample 398D-123-5, $72 \mathrm{~cm}$, of early Aptian age. Groot and Groot (1962) recovered T. bernissartensis in a sample collected from the early Bellasian (local stage) near Nazaré (Portugal). An early Aptian age can be assigned to early Bellasian in this region. In southeastern France, $T$. bernissartensis occurs in the basal portion of the Aptian but not in the Barremian stratotype (de Renéville and Raynaud, 1981). It was also not recorded by Srivastava (1984) in the Barremian section of the same region. Because of the presence of this species, we therefore infer a Barremian to early Aptian age for Samples 103-638B-22R-4, $59 \mathrm{~cm}$, and 103-638B-23R-2, $34 \mathrm{~cm}$. This species has not been recovered in Hole $638 \mathrm{C}$.

Foveosporites subtriangularis was recovered from Samples 103-638B-28R-6, $89 \mathrm{~cm}$, up to $103-641 \mathrm{C}-14 \mathrm{R}-4,32 \mathrm{~cm}$. This spe- 
Table 2. Stratigraphic distribution of spores and pollen grains in Hole 638C. Star $=$ index species. Species list is given in the Appendix.

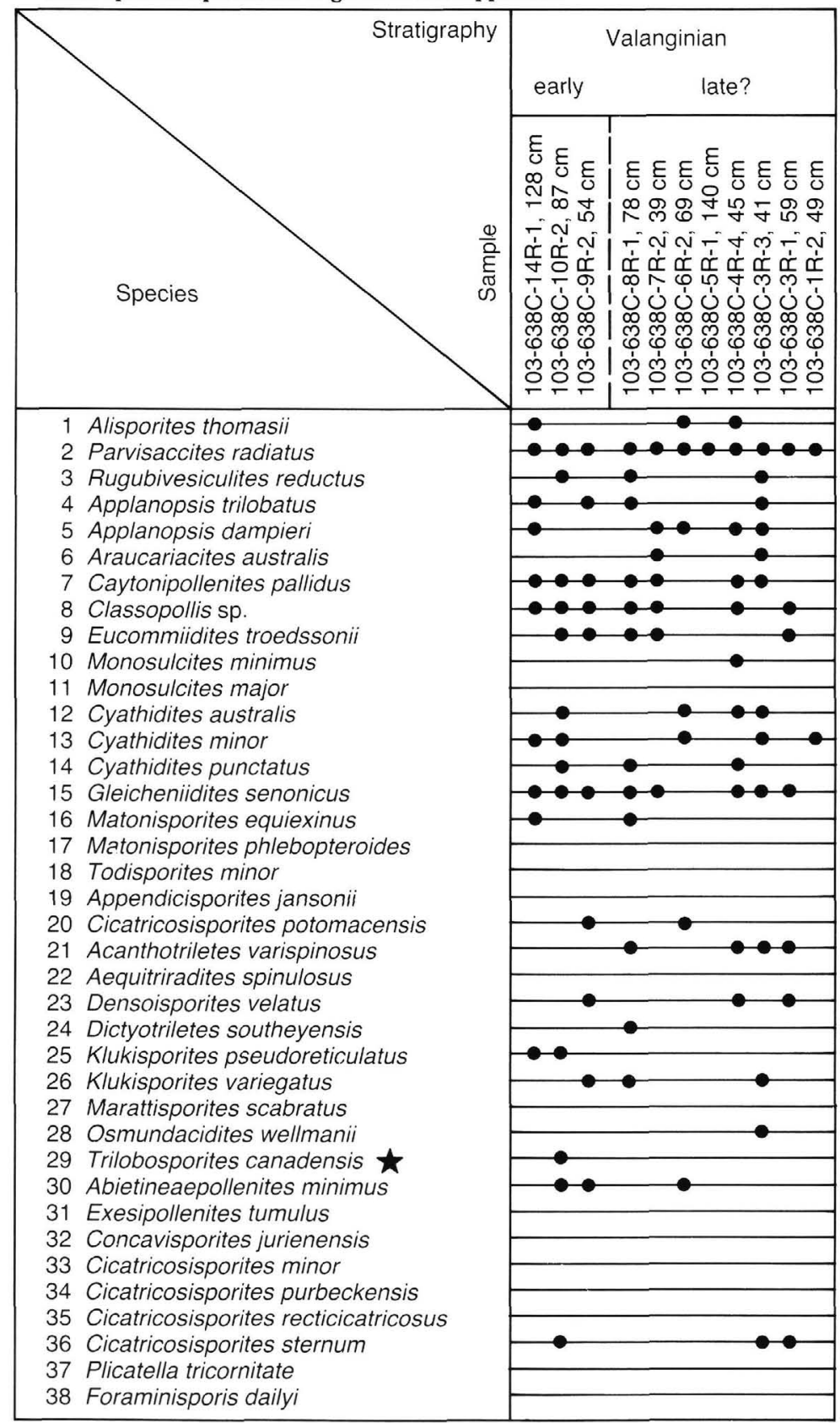

cies has been previously described from a number of different localities. It was first described by Brenner (1963) from the Barremian to Albian section of the Atlantic coastal plain of Maryland. Burger (1966) recovered it from the upper Berriasian of the eastern Netherlands. In Germany, Döring (1966) recorded it mainly from the Hauterivian and rarely in younger strata. De Renéville and Raynaud (1981) observed it in the Barremian stratotype but not in the underlying Hauterivian section. In the Algarve, Berthou et al. (1983) found $F$. subtriangularis only in the Barremian. In England, Kemp (1980) recorded this species in strata as young as early Albian. Arias and Doubinger (1980) found it similarly in the lower Albian of southeastern Spain. At Hole 398D, F. subtriangularis occurs from Samples 398D-133$2,142 \mathrm{~cm}$, of Hauterivian-Barremian age, up to 398D-118-4, $113 \mathrm{~cm}$, of late Aptian age (age assignments after Müller et al., 1983, 1984). At Hole 402A, Batten (1979) recovered this species from Samples $402 \mathrm{~A}-23-6,35-38 \mathrm{~cm}$, to $402 \mathrm{~A}-25-5,5-8 \mathrm{~cm}$, of early Albian age. In comparison with these other occurrences, a Hauterivian age for Sample 103-638B-28R-6, $89 \mathrm{~cm}$, can be inferred from the first appearance of $F$. subtriangularis.

Parvisaccites amplus occurs from Samples 103-638B-29R-3, $35 \mathrm{~cm}$, up to $103-641 \mathrm{C}-11 \mathrm{R}-2,114 \mathrm{~cm}$. It was not recovered in Hole 638C. In Hole 398D, it occurs in Sample 398D-136-1, 112 $\mathrm{cm}$, of late Hauterivian age (Müller et al., 1983, 1984). Brenner (1963), who originally described $P$. amplus, stated that it is a rare species in his zone I of Barremian-Aptian age. The first presence of $P$. amplus, in comparison with Hole 398D results, implies a possible Hauterivian age for Sample 103-638B-29R-3, $35 \mathrm{~cm}$.

Ephedripites cf. multicostatus has its first appearance in Sample 103-638B-23R-2, $34 \mathrm{~cm}$. It is absent up to Sample 103-641C$16 \mathrm{R}-8,25 \mathrm{~cm}$, from which it is continuously recovered up to 
Table 2 (continued).

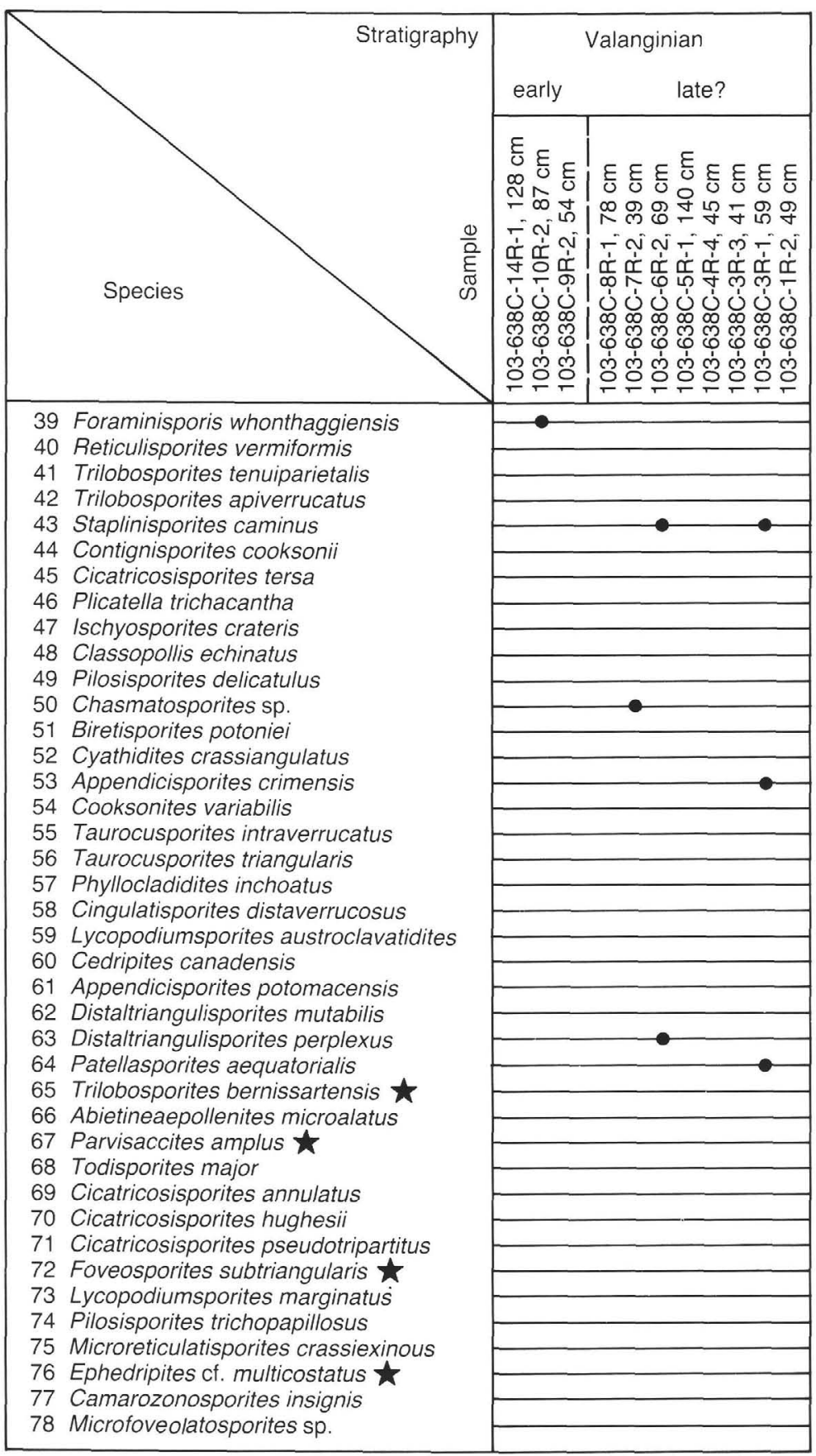

Sample 103-641C-11R-2, $114 \mathrm{~cm}$. At Site 398D, the Chlamydospermales pollen (genera Ephedripites and Welwitschiapites) occur from Samples 398D-99-1, $12 \mathrm{~cm}$, up to 398D-65-1, $68 \mathrm{~cm}$, dated as early to late Albian. In the western North Atlantic, Ephedripites multicostatus is an index species from the Berriasian to the late Hauterivian (Habib, 1977, 1978). However Dörhöffer and Norris (1975) and Dörhöffer (1979) did not mention this species near the Jurassic/Cretaceous boundary. There is a noticeable difference in the distribution of this species on each side of the Atlantic. Hughes and McDougall (1987) recovered the first Ephedripites pollen in the uppermost Hauterivian section of southern and eastern England, where it was previously known (Kemp, 1970) from only the Barremian and lower Aptian. Deàk and Combaz (1967) described Ephedripites translucidus, a spe- cies similar to $E$. multicostatus, from the upper Albian/lower Cenomanian in western France. De Renéville and Raynaud (1981) recovered Ephedripites sp. from the upper Barremian stratotype. The same pollen recovered by Srivastava (1984) in the Barremian from southeastern France appears to possess thicker ribs than E. multicostatus. Ephedripites was not recovered from the Barremian of the Algarve (Berthou et al., 1983). Groot and Groot (1962) recovered Ephedripites sp. in a sample of late Albian to early Cenomanian age from Nazaré (Portugal). Hasenboehler (1981) recovered $E$. multicostatus from the middle and upper Albian, and Moron (1981) recovered it from the middle Cenomanian of the Occidental Portuguese Basin. Arias and Doubinger (1980) found the species in the lower Albian of southeastern Spain. Based on comparison with these other oc- 
currences, we propose a latest Hauterivian-early Barremian age for the first occurrence of E. multicostatus in Sample 103-638B23R-2, $34 \mathrm{~cm}$, and a Barremian to early Aptian age for its subsequent occurrence in Sample 103-641C-16R-8, $18 \mathrm{~cm}$.

\section{CONCLUSIONS}

In spite of pyritization, about 80 spores and pollen species from Sites 638 and 641 were documented and plotted on two range charts (Tables 1 and 2). Early Cretaceous spores and pollen grains are generally not reliable stratigraphic fossils because many species are long-ranging taxa, and their distribution depends on paleogeography and plant migrations. But in continental basins, a regional zonation is still possible.

In deep marine sediments another difficulty is imposed by the loss or destruction during marine transport of some important taxa of spores and pollen. Site 638 was drilled on the outer part of the Iberian margin, and during the Valanginian, the site was nearer Newfoundland than the Iberian continent. But comparison with continental palynological deposits of same age and assemblages as those recovered in Hole 398D indicates that the land plant sporomorphs were derived from European terrigenous sediments and were transported a great distance, or resedimented. Thus, at Site 638, the genus Trilobosporites is very scarce in the assemblages and the size of the specimens very small. Furthermore, the first Barremian angiosperm pollen, genus Clavatipollenites, was not recovered at Site 638. In Hole 398D, it did not occur before the late Aptian; Batten (1979) did not mention it for Sites 400 and 402 .

The stratigraphically significant species are summarized on Figure 2. The turbidites recovered in Hole 638B from Samples 103-638B-32R-2, $95 \mathrm{~cm}$, through 103-638B-45R, CC $(25 \mathrm{~cm})$, and 103-638C-1R-1, $0 \mathrm{~cm}$, through 103-638C-14, CC $(30 \mathrm{~cm})$, are Valanginian. In Hole $641 \mathrm{C}$ the microturbidites and turbidites recovered from Sample 103-641C-8R-1, $0 \mathrm{~cm}$, through Section 103-641C-16R, CC, are Aptian-Barremian. Comparison of the relative frequency histograms of spores and pollens in the turbidites from Holes 638B and 638C (Fig. 3) shows that in Samples 103-638B-34R-2, $95 \mathrm{~cm}$, and 103-638C-9R-2, $54 \mathrm{~cm}$, an

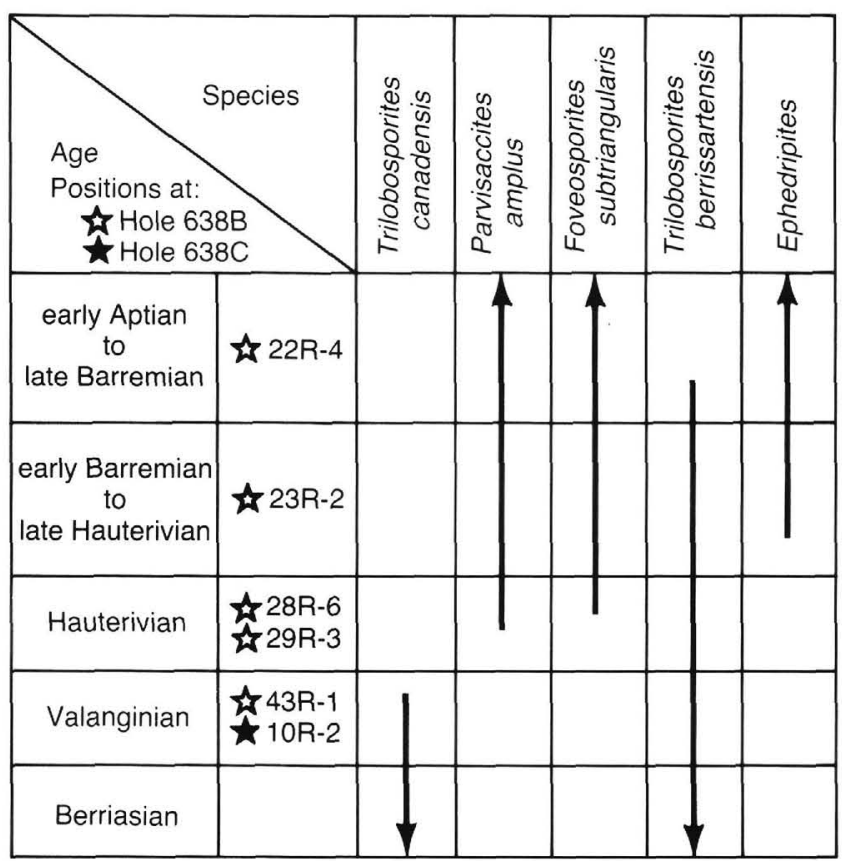

Figure 2. Stratigraphic occurrence of spore and pollen index species at Site 638. increase of spores corresponds to smaller percentages of all pollen taxa. This suggests that the spores and pollens in these beds were sedimented rapidly without sorting by marine currents. In other samples, an increase of buoyant Disaccites corresponds to a decrease of spores and Classopollis, which suggests sorting by marine currents, as was observed in Hole 398D (TaugourdeauLantz et al., 1982). In conclusion, dating of these turbidites extends the syn-rift period of the Galicia margin back to at least the Valanginian.

\section{REFERENCES}

Arias, C., and Doubinger, J., 1980. La limite Aptien-Albien dans le secteur du Mompichel (Albacete). Cretaceous Res., 1:235-251.

Balme, B. E., 1957. Spores and pollen grains from the Mesozoic of western Australia. CSIRO Abstr., 1:48.

Batten, D. J., 1973. Palynology of Early Cretaceous soil beds and associated strata. Paleontology, 16:399-424.

1979. Miospores and other acid-resistant microfossils from the Aptian/Albian of Holes 400A and 402A, DSDP-IPOD Leg 48, Bay of Biscay. In Montadert, L., Roberts, D. G., et al., Init. Repts $D S D P$, 48: Washington (U.S. Govt. Printing Office), 579-587.

Berthou, P.-Y., Correia, F., Prates, S., and Taugourdeau, J., 1983. Essai de synthèse du Crétacé de l'Algarve: biostratigraphie, paléogéographie, sédimentation argileuse. 1ère partie: biostratigraphie et paléogéographie. Bull. Inf. Geol. Bassin Paris, 20:3-24.

Brenner, G. J., 1963. The spores and pollen of the Potomac Group of Maryland. Bull. Md. Geol. Surv., 27:1-215.

Burger, D., 1966. Palynology of uppermost Jurassic and lowermost Cretaceous strata in the eastern Netherlands. Leidse Geol. Meded., 35: 209-276.

Couper, R. A., 1958. British Mesozoic microspores and pollen grains. A systematic and stratigraphic study. Palaeontographica Abt. B, 103: 75-179.

Deàk, M. H., and Combaz, A., 1967. "Microfossiles organiques" du Wealdien et du Cénomanien dans un sondage de Charente-Maritime. Rev. Micropaleontol., 10:69-96.

Delcourt, A. F., Dettmann, M. E., and Hughes, N. F., 1963. Révision of some Lower Cretaceous miospores from Belgium. Paleontology, 6:282-292.

Delcourt, A. F., and Sprumont, G., 1955. Les spores et grains de pollen du Wealdien du Hainaut. Mem. Soc. Belge Geol. Paleontol. Hydrol., 4:1-83.

de Renéville, P., and Raynaud, J. P., 1981. Palynologie du stratotype du Barrémien. Bull. Centr. Rech. Explor. Prod. Elf Aquitaine, 5:1-29.

Dettmann, M. E., 1963. Upper Mesozoic microfloras from southeastern Australia. Proc. R. Soc. Victoria, 77:1-148.

Dörhöffer, G., 1977. Palynologie und stratigraphie der Bückeberg Formation (Berriasium-Valanginium) in der Hilsmulde (NW-Deutschland). Geol. Jahrb., Reihe A, 42:1-122.

1979. Distribution and stratigraphic utility of Oxfordian to Valanginian microspores in Europe and North America. AASP Contrib. Ser. $B, 5: 101-132$.

Dörhöffer, G., and Norris, G., 1975. Discrimination and correlation of highest Jurassic and lowest Cretaceous terrestrial palynofloras in Northwest Europe. Palynology, 1:79-93.

Döring, H., 1966. Sporenstratigraphischer Vergleich zwischen dem Wealden Norddeutschlands und Sudenglands. Geol. Jahrb., Reihe B, 55:102115.

Groot, J. J., and Groot, C. R., 1962. Plant microfossils from Aptian, Albian and Cenomanian deposits of Portugal. Comun. Serv. Geol. Port., 46:133-171.

Habib, D. 1977. Comparison of Lower and middle Cretaceous palynostratigraphic zonation in the western North Atlantic. In Swain, F. M. (Ed.), Stratigraphic Micropaleontology of Atlantic Basin and Borderlands: Amsterdam (Elsevier), 341-392.

1978. Palynostratigraphy of the Lower Cretaceous section at Deep Sea Drilling Project, Site 391, Blake-Bahama Basin, and its correlation in the North Atlantic. In Benson, W. E., Sheridan, R. E., et al., Init. Repts. DSDP, 44: Washington (U.S. Govt. Printing Office), 887-897.

1979a. Sedimentology of palynomorphs and palynodebris in Cretaceous carbonaceous facies, south of Vigo Seamount. In Sibuet, J.-C., Ryan, W.B.F., et al., Init. Repts. DSDP, 47, Pt. 2: Washington (U.S. Govt. Printing Office), 451-460. 
1979b. Sedimentary origin of North Atlantic Cretaceous palynofacies. In Talwani, M., Hay, W., and Ryan, W.B.F. (Eds.), Deep Drilling Results in the Atlantic Ocean: Continental Margins and Paleoenvironment: Am. Geophys. Union, Maurice Ewing Ser., 3:420 437.

Hasenboehler, B., 1981. Etude paléobotanique et palynologique de l'Albien et du Cénomanien du Bassin Occidental portugais au Sud de l'accident de Nazaré (province d'Estramadure, Portugal) [Thesis]. Univ. P. et M. Curie, Paris.

Hughes, N. F., and Croxton, C. A., 1973. Palynologic correlation of the Dorset "Wealden." Paleontology, 16:567-661.

Hughes, N. F., and McDougall, A. B., 1987. Records of Angiospermid pollen entry into the English Early Cretaceous succession. Rev. $\mathrm{Pa}$ leobot. Palynol., 50:255-272.

Hughes, N. F., and Moody-Stuart, J., 1966. Descriptions of Schizaeaceous spores taken from Early Cretaceous macrofossils. Paleontology, 9:274-289.

Kemp, E. M., 1970. Aptian and Albian miospores from southern England. Palaeontographica Abt. B, 131:73-143.

Kotova, I. Z., 1978. Spores and pollen from Cretaceous deposits of the eastern North Atlantic Ocean, Deep Sea Drilling Project Leg 41, Sites 367 and 370. In Lancelot, Y., Seibold, E., et al., Init. Repts $D S D P$, 41: Washington (U.S. Govt. Printing Office), 841-852.

Moron, J. M., 1981. Etude paléobotanique et palynologique du Crétacé superieur (Portugal) [Thesis]. Univ. P. et M. Curie, Paris.

Müller, C., Schaaf, A., and Sigal, J., 1983. Biochronostratigraphie des formations d'âge crétacé dans les forages du DSDP dans l'Océan Atlantique Nord. 1ère partie. Rev. Inst. Fr. Pet., 38:683-708.

1984. Biochronostratigraphie des formations d'âge crétacé cans les forages du DSDP dans l'Océan Atlantique Nord. 2ème partie. Rev. Inst. Fr. Pet., 39:3-23.

Norris, G., 1967. Spores and pollen from the Lower Colorado Group (Albian-?Cenonanian) of central Alberta. Palaeontographica Abt. $B, 120: 72-115$.

1969. Miospores from the Purbeck Beds and marine Upper Jurassic of southern England. Paleontology, 12:574-620.

Pierce, R. L., 1961. Lower Upper Cretaceous plant microfossils from Minnesota. Bull. Minn. Geol. Surv., 42:1-86.

Pocock, S.A.J., 1962. Microfloral analysis and age determination of strata at the Jurassic boundary in the western Canada Plains. Palaeontographica Abt. B, 3:1-95.

, 1964. Pollen and spores of the Chlamydospermidae and Schizaeaceae from upper Mannville strata of the Saskatoon area of Saskatchewan. Grana Palynologica, 5:129-209.

Potonié, R., 1951. Revision stratigraphisch wichtiger Sporomorphen des mitteleuropaïschen Tertiärs. Palaeontographica Abt. B, 9:131151 .

, 1956. Synopsis der Gattungen der Sporae Dispersae, Teil I. Geol. Jahrb. Beih., 23:1-123.

1960. Synopsis der Gatlungen der Sporae Dispersae. Teil III Geol. Jahrb. Beih., 39:1-189.

Rouse, C. E., 1959. Plant microfossils from Kootenay coal measures strata of British Columbia. Micropaleontology, 5:303-324.

Shipboard Scientific Party, 1987a. Site 638. In Boillot, G., Winterer, E L., et al., Proc. ODP, Init. Repts., 103: College Station, TX (Ocean Drilling Program), 221-407.

1987b. Site 641. In Boillot, G., Winterer, E. L., et al., Proc. $O D P$, Init. Repts., 103: College Station, TX (Ocean Drilling Program), 571-649.

Sibuet, J.-C., Ryan, W.B.F., et al., 1979. Init. Repts. DSDP, 47, Pt. 2: Washington (U.S. Govt. Printing Office).

Singh, C., 1964. Microflora of the Lower Cretaceous Mannville Group, east-central Alberta. Earth Sci. Rep. Alberta Res. Counc., 15:1-237. 1971. Lower Cretaceous microfloras of the Peace River Area, northwestern Alberta. Earth Sci. Rep. Alberta Res. Counc., 28:1300 .

Srivastava, S. K., 1981. Stratigraphic ranges of selected spores and pollen from the Fredericksburg Group (Albian) of the southern United States. Palynology, 5:1-26.

1984. Barremian dinoflagellate cysts from southeastern France. Cah. Micropaleontol., 2:1-90.

Taugourdeau-Lantz, J., Azéma, C., Hasenboehler, B., Masure, E., and Moron, J. M., 1982. Evolution des domaines continentaux et marins de la marge portugaise (Leg 47B, Site 398D) au cours du Crétacé:
Essai d'interprétation par l'analyse palynologique comparée. Bull. Soc. Geol. Fr. 24:447-459.

Taugourdeau-Lantz, J., and Donze, P., 1971. Un aperçu de l'environnement végétal pendant l'épisode régressif du Berriasien terminal dans le Jura Méridional (France). Rev. Micropaleontol., 14:102-120.

Date of initial receipt: 29 April 1987

Date of acceptance: 5 January 1988

Ms 103B-151

\section{APPENDIX \\ Species List}

The number in parentheses corresponds to the species number in the distribution charts (Tables 1 and 2).

\section{Sporites}

Ante-turma Proximegerminantes, turma Triletes, subturma Azonotriletes

Biretisporites potoniei Delcourt and Sprumont, 1955. (51)

Concavisporites jurienensis Balme, 1957; Pl. 1, Fig. 13. (32) Synonymes: Deltoidospora juncta (Kara Murza); Gleicheniidites apilobatus Brenner, 1963.

Cyathidites australis (Cookson) Couper, 1958. (12)

Cyathidites crassiangulatus Brenner, 1963. (52)

Cyathidites minor Couper, 1958. (13)

Cyathidites punctatus (Delcourt and Sprumont) Delcourt et al., 1963; Pl. 1, Fig. 5. (14)

Gleicheniidites senonicus Ross, 1949. (15)

Matonisporites equiexinus Couper, 1958; Pl. 2, Fig. 11. (16)

Matonisporites phlebopteroides Couper, 1958. (17)

Todisporites major Couper, 1958. (68)

Todisporites minor Couper, 1958. (18)

Osmandacidites wellmanii Couper, 1953; P1. 1, Fig. 2. (28)

Lycopodiumsporites austroclavatidites (Cookson) R. Potonié, 1956 (59)

Lycopodiumsporites marginatus Singh, 1964. (73)

Dictyotriletes southeyensis Pocock, 1962. (24)

Ischyosporites crateris Balme, 1957. (47)

Klukisporites pseudoreticulatus Couper, 1958. (25)

Klukisporites variegatus Couper, 1958. (26)

Reticulisporites vermiformis Kemp, 1970. (40)

Foraminisporis dailyi (Cookson and Dettmann) Dettmann, 1963. (38)

Foraminisporis whonthaggiensis (Cookson and Dettmann) Dettmann 1963. (39)

Acanthotriletes varispinosus Pocock, 1962. (21)

Pilosisporites delicatulus Norris, 1969. (49)

Pilosisporites trichopapillosus (Thiergart) Delcourt and Sprumont, 1955. (74)

Appendicisporites crimensis (Bolchovitina) Pocock, 1964. (53)

Appendicisporites jansonii Pocock, 1962. (19)

Appendicisporites potomacensis Brenner, 1963. (61)

Cicatricosisporites annulatus Archangelsky and Gamerro, 1966. (69)

Cicatricosisporites hughesii Dettmann, 1963. (70)

Cicatricosisporites minor (Bolchovitina) Pocock, 1964; P1. 1, Fig. 7. (33)

Cicatricosisporites potomacensis Brenner, 1963; Pl. 1, Fig. 10. (20)

Cicatricosisporites pseudotripartitus (Bolchovitina) Dettmann, 1963; P1. 1, Fig. 1. (71)

Cicatricosisporites purbeckensis Norris, 1969; P1. 2, Fig. 9. (34)

Cicatricosisporites recticicatricosus Döring, 1965. (35)

Cicatricosisporites sternum Burger, 1966; P1. 1, Fig. 11. (36)

Cicatricosispcrites tersa (Kara Murza) Pocock, 1964. (45)

Contignisporites cooksoni (Balme) Dettmann, 1963. (44)

Plicatella trichacantha (Maljavkina). (46)

Plicatella tricornitata (Weyland and Krieger) R. Potonié, 1960. (37)

Subturma Zonotriletes

Aequitriradites spinulosus (Cookson and Dettmann) Cookson and Dettmann, 1961; Pl. 2, Fig. 2. (22)

Camarozonosporites insignis Norris, 1967; Pl. 2, Fig. 10. (77)

Cingulatisporites distaverrucosus Brenner, 1963. (58)

Cooksonites variabilis Pocock, 1962. (54) 


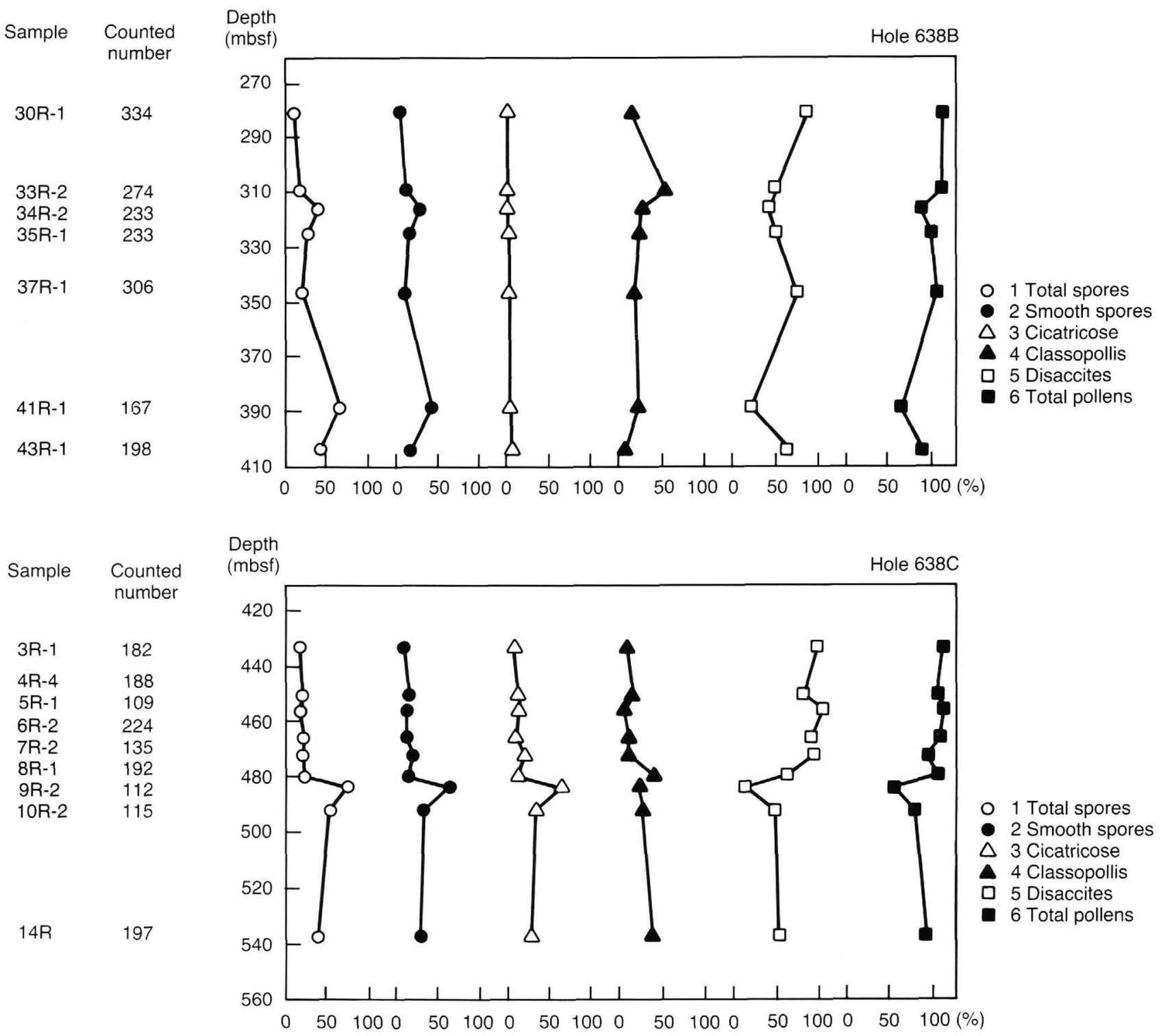

Figure 3. Relative frequency histogram of spores and pollen grains at Holes $638 \mathrm{~B}$ and $638 \mathrm{C}$.

Densoisporites velatus Weyland and Krieger, 1953. (23)

Distaltriangulisporites perplexus (Singh) Singh, 1971; Pl. 1, Figs. 3 and 4. (63)

Distaltriangulisporites mutabilis Singh, 1971. (62)

Foveosporites subtriangularis (Brenner) Döring, 1966. (72)

Patellasporites aequatorialis Krutzsch, 1959. (64)

Staplinisporites caminus (Balme) Pocock, 1962; Pl. 1, Fig. 8. (43)

Taurocusporites intraverrucatus (Brenner, 1963); Pl. 1, Fig. 12. (55)

Taurocusporites triangularis (Brenner). (56)

Trilobosporites apiverrucatus Couper, 1958; Pl. 1, Fig. 15. (42)

Trilobosporites bernissartensis Delcourt and Sprumont, 1955. (65)

Trilobosporites canadensis Pocock, 1962; Pl. 1, Fig. 6. (29)

Trilobosporites tenuiparietalis Döring, 1965; Pl. 1, Fig. 14. (41)

\section{Turma Monoletes}

Marattisporites scabratus Couper, 1958. (27)

Microfoveolatosporites sp. Kemp, 1970. (78)

Turma Saccites

Abietineaepollenites microalatus R. Potonié, 1951. (66)

Abietineaepollenites minimus Couper, 1958. (30)

Alisporites thomasii (Couper) Pocock, 1962. (1) Synonyme: Alisporites bilateralis Rouse, 1959.
Caytonipollenites pallidus (Reissinger) Couper, 1958; Pl. 1, Fig. 9. (7)

Cedripites canadensis Pocock, 1962; Pl. 2, Fig. 6. (60)

Parvisaccites amplus Brenner, 1963; Pl. 2, Fig. 1. (67)

Parvisaccites radiatus Couper, 1958; Pl. 2, Fig. 7. (2)

Phyllocladidites inchoatus (Pierce) Norris, 1967. (57)

Rugubivesiculites reductus Pierce, 1961 sensu Burger, 1966; P1. 2, Fig. 4. (3)

\section{Turma Kryptaperturates}

Applanopsis dampieri (Balme) Döring, 1961. (5)

Applanopsis trilobatus (Balme) Goubin et al., 1965. (4)

Araucaruacites australis Cookson, 1947; Pl. 2, Fig. 8. (6)

Cerebropollenites mesozoicus (Couper) Nilsson, 1958.

Cerebropollenites $\mathrm{sp}$.

Classopollis echinatus Burger, 1966; Pl. 2, Fig. 3. (48)

Exesipollenites tumulus Balme, 1957. (31)

\section{Turma Plicates}

Chasmatosporites $\mathrm{sp}$. (50)

Ephedripites cf. multicostatus Brenner, 1963; Pl. 1, Fig. 16. (76)

Eucommidiites troedssonii Erdtman, 1948; Pl. 2, Fig. 5. (9)

Monosulcites major Kemp, 1970. (11)

Monosulcites minimus Cookson, 1953; Pl. 2, Fig. 2. (10) 


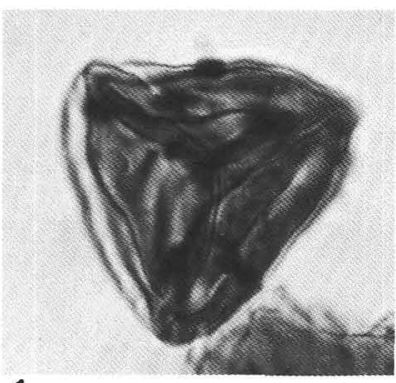

1

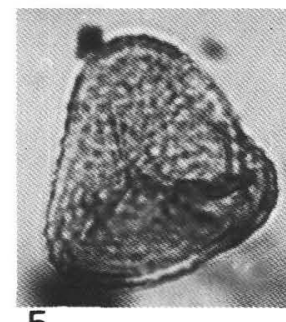

5

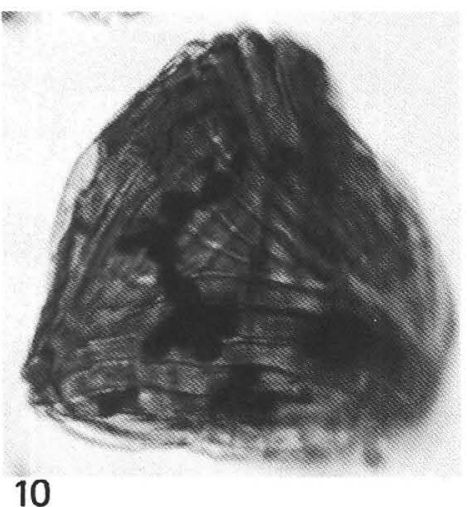

10

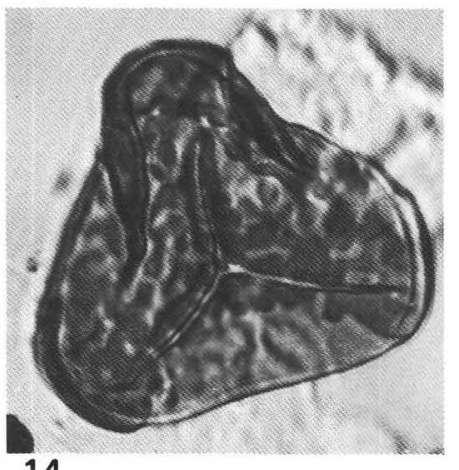

14

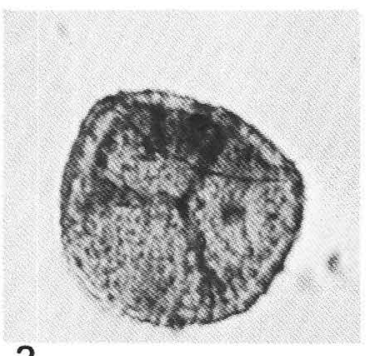

2
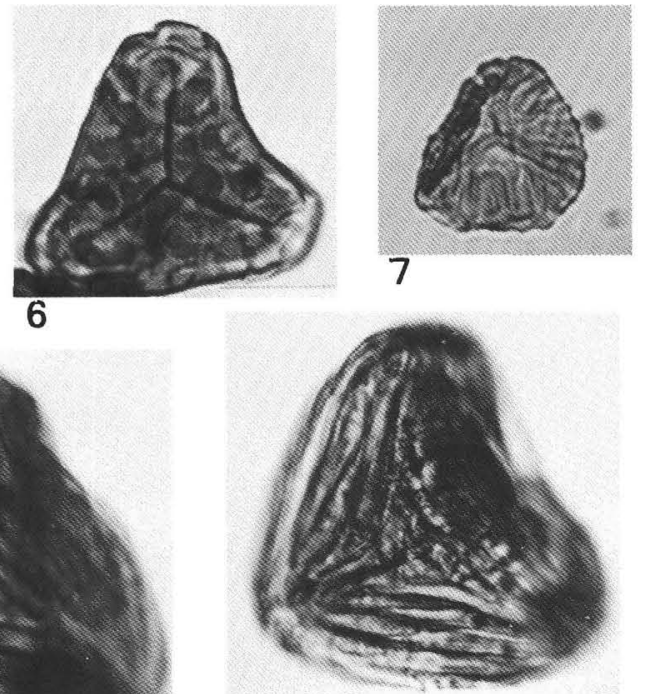

11

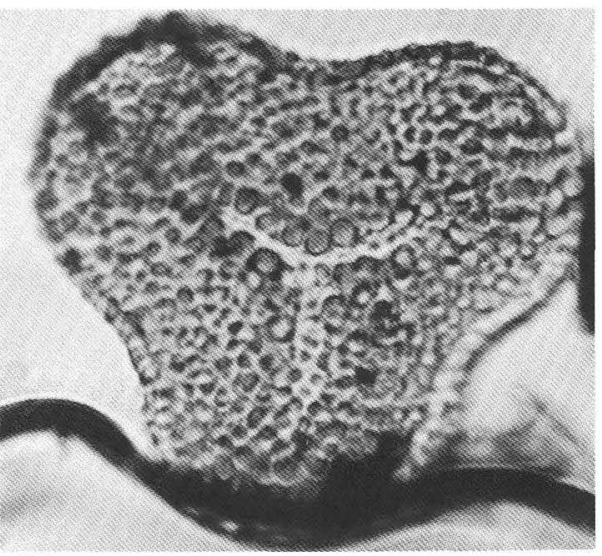

15
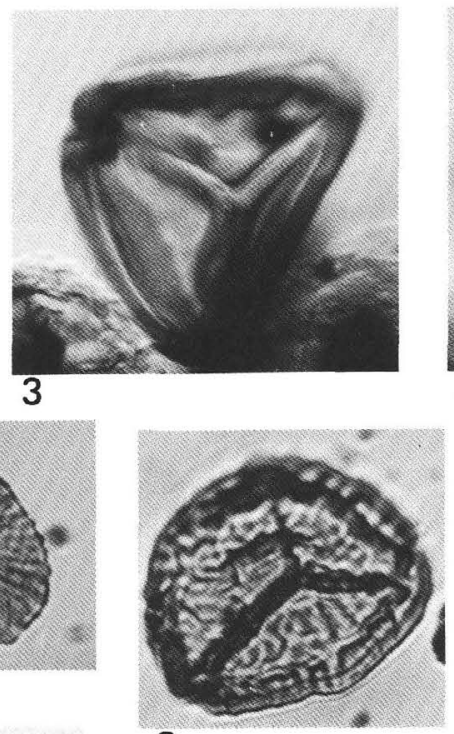

8

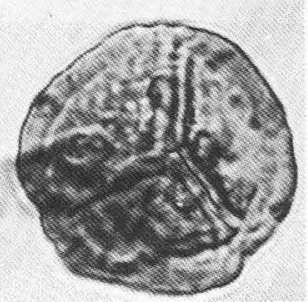

12

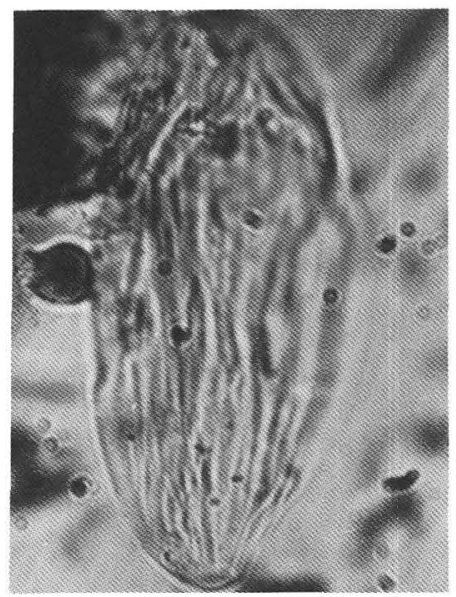

16
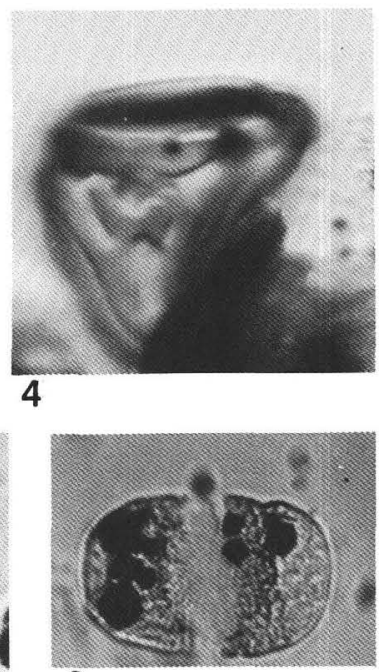

9

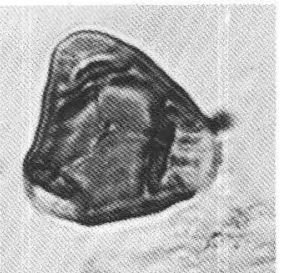

13

Plate 1. Early Cretaceous spores and pollen grains. 1. Cicatricosisporites pseudotripartitus (Bolchovitina) Dettmann, 1963. Sample 103-638B-21R3, $128 \mathrm{~cm}$. Size: $37.5 \mu \mathrm{m}$. 2. Osmundacidites wellmannii Couper, 1953. Sample 103-638C-3R-3, $41 \mathrm{~cm}$. Size: $32 \mu \mathrm{m}$. 3 and 4. Distaltriangulisporites perplexus (Singh) Singh, 1971. Sample 103-638B-26R-3, $91 \mathrm{~cm}$. Size: $40 \mu \mathrm{m}$. 5. Cyathidites punctatus (Delcourt and Sprumont) Delcourt et al., 1963. Sample 103-638B-43R-1, $29 \mathrm{~cm}$. Size $30 \mu \mathrm{m}$. 6. Trilobosporites canadensis Pocock, 1962. Sample 103-638B-43R-1, $29 \mathrm{~cm}$. Size: $35 \mu \mathrm{m}$. 7. Cicatricosisporites minor (Bolchovitina) Singh, 1971. Sample 103-638B-37R-1, $46 \mathrm{~cm}$. Size: $24 \mu \mathrm{m}$. 8. Staplinisporites caminus (Balme) Pocock, 1962. Sample 103-638B-37R-1, $46 \mathrm{~cm}$. Size: $37 \mu \mathrm{m}$. 9. Caytonipollenites pallidus (Reissinger) Couper, 1958 . Sample 103-638B-37R-1, $46 \mathrm{~cm}$. Size: 35 $\times 24 \mu \mathrm{m}$. 10. Cicatricosisporites potomacensis Brenner, 1963. Sample 103-638B-37R-1, $46 \mathrm{~cm}$. Size: $60 \mu \mathrm{m}$. 11. Cicatricosisporites sternum Burger, 1966. Sample 103-638C-3R-3, $41 \mathrm{~cm}$. Size: $52 \mu \mathrm{m}$. 12. Taurocusporites intraverrucatus Brenner, 1963. Sample 103-638B-37R-1, $43 \mathrm{~cm}$. Size: $36 \mu \mathrm{m}$. 13. Concavisporites jurienensis Balme, 1957. Sample 103-638B-37R-1, $43 \mathrm{~cm}$. Size: $25 \mu \mathrm{m}$. 14. Trilobosporites tenuiparietalis Döring, 1965. Sample 103-638B-37R-1, $43 \mathrm{~cm}$. Size: $50 \mu \mathrm{m}$. 15. Trilobosporites apiverrucatus Couper, 1958. Sample 103-638B-37R-1, 43 cm. Size: 67.5 $\mu \mathrm{m}$. 16. Ephedripites cf. multicostatus Brenner, 1963. Sample 103-638B-23R-2, $34 \mathrm{~cm}$. Size: $45 \times 21 \mu \mathrm{m}$. 


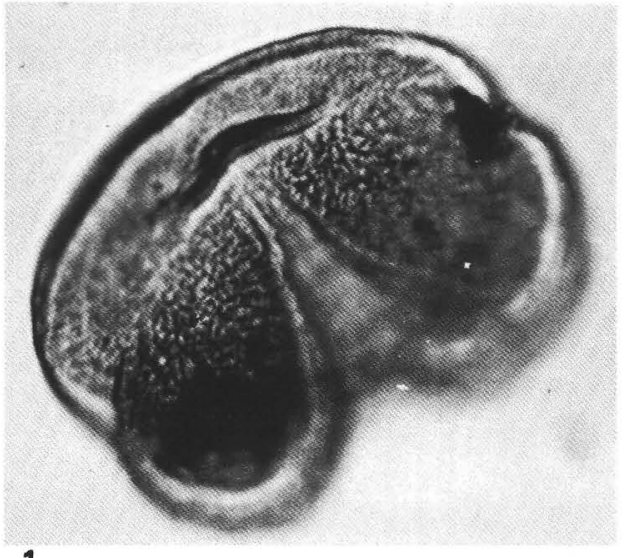

1

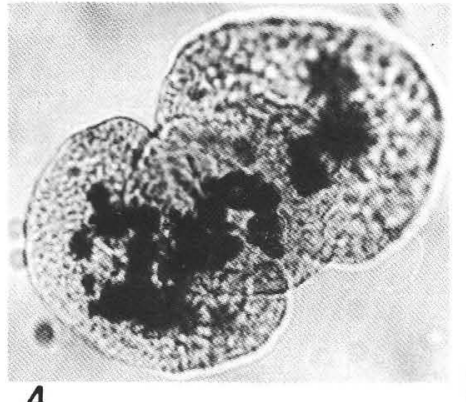

4
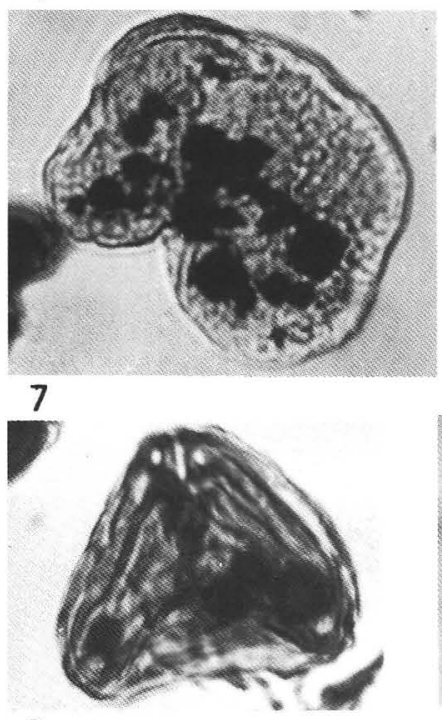

9

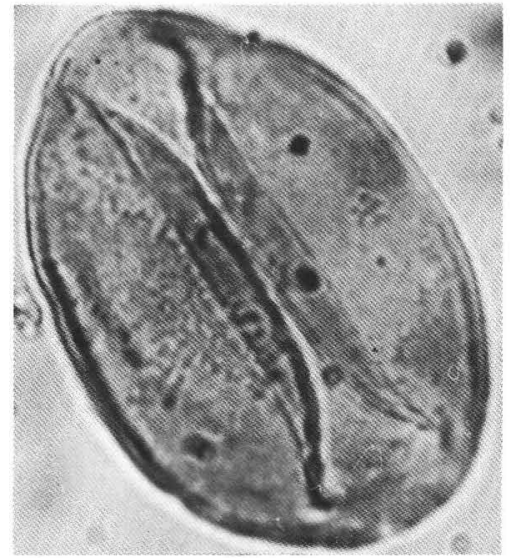

2

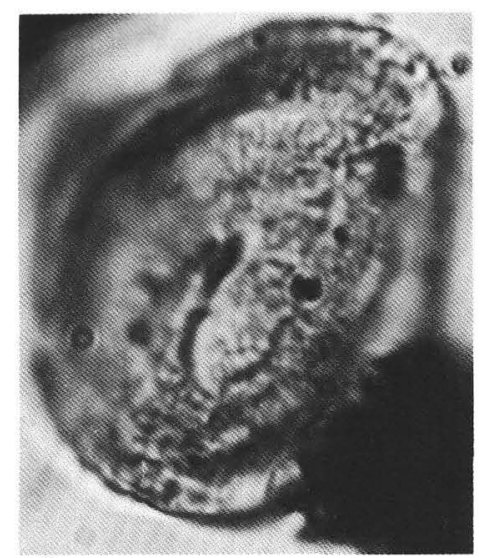

3

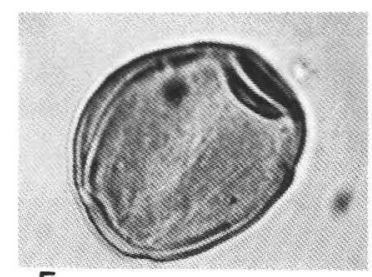

5
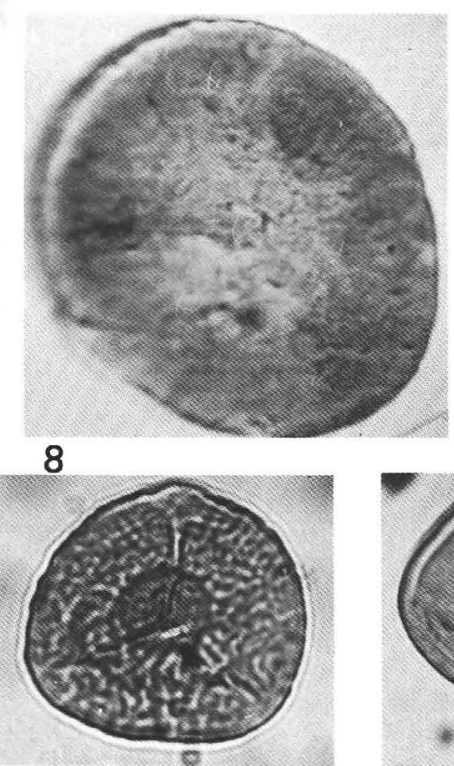

10

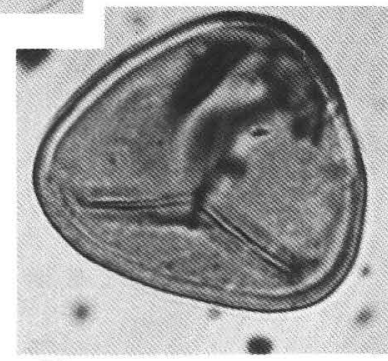

11

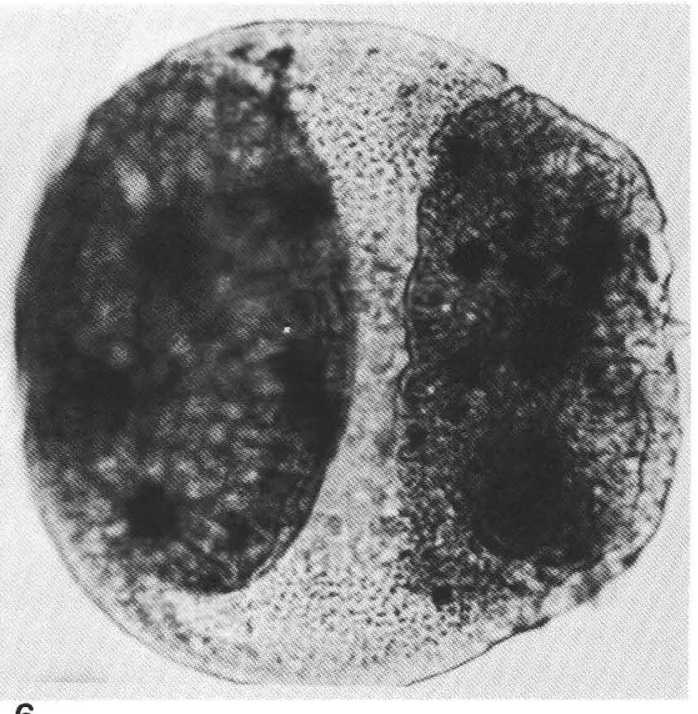

6

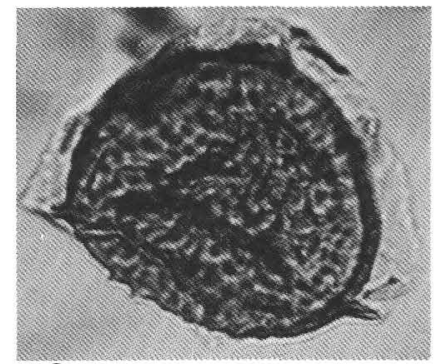

12

Plate 2. Early Cretaceous spores and pollen grains. 1. Parvisaccites amplus Brenner, 1963. Sample $641 \mathrm{C}-14 \mathrm{R}-4,32 \mathrm{~cm}$. Size: $74 \times 90 \mu \mathrm{m}$. 2 . Monosulcites minimus Cookson, 1953. Sample 103-638B-41R-2, $12 \mathrm{~cm}$. Size: $32 \times 21 \mu \mathrm{m}$. 3. Classopollis echinata Burger, 1966. Sample 103-638B43R-1, $29 \mathrm{~cm}$. Size: $29 \times 23 \mu \mathrm{m}$. 4. Rugubivesiculites reductus Pierce, 1961 sensu Burger, 1966 . Sample 103-638C-7R-2, $39 \mathrm{~cm}$. Size: $60 \times 37.5$ $\mu \mathrm{m}$. 5. Eucommiidites troedssonii Erdtmann, 1943. Sample 103-638B-37R-1, $46 \mathrm{~cm}$. Size: $32.5 \times 25.5 \mu \mathrm{m}$. 6. Cedripites canadensis Pocock, 1962. Sample 103-641C-14R-4, $32 \mathrm{~cm}$. Size: $90 \mu \mathrm{m}$. 7. Parvisaccites radiatus Couper, 1958. Sample 103-638C-7R-2, $39 \mathrm{~cm}$. Size: $46.5 \times 37 \mu \mathrm{m}$. 8 . Araucariacites australis Cookson, 1947. Sample 103-638C-3R-3, $41 \mathrm{~cm}$. Size: $55 \mu \mathrm{m}$. 9. Cicatricosisporites purbeckensis Norris, 1969. Sample 103638B-37R-1, $46 \mathrm{~cm}$. Size: $35 \mu \mathrm{m}$. 10. Camarozonosporites insignis Norris, 1967. Sample 103-641C-14R-4, $32 \mathrm{~cm}$. Size: $35 \mu \mathrm{m}$. 11. Matonisporites equiexinus Couper, 1958. Sample 103-641C-14R-4, $32 \mathrm{~cm}$. Size: $40 \mu \mathrm{m}$. 12. Aequitriradites spinulosus (Cookson and Dettmann) Dettmann, 1963. Sample 103-638B-43R-1, $29 \mathrm{~cm}$. Size: $50 \mu \mathrm{m}$. 